
\title{
25 Research Soure \\ Bottom-Up and Top-Down Controls of Litter Decomposition Rates and N Dynamics in Arid Steppes.
}

Maria-Victoria Piazza ( $\square$ victoriapiazza@gmail.com )

Universidad de Buenos Aires Facultad de Agronomia https://orcid.org/0000-0002-6185-4195

Gaston R. Oñatibia

Universidad de Buenos Aires Facultad de Agronomia

Martin R. Aguiar

Universidad de Buenos Aires Facultad de Agronomia

\section{Manuscript}

Keywords: ecosystem functioning, grazing intensification, litter traits, Patagonian arid steppe

Posted Date: January 29th, 2021

DOI: https://doi.org/10.21203/rs.3.rs-157914/v1

License: (c) (i) This work is licensed under a Creative Commons Attribution 4.0 International License.

Read Full License

Version of Record: A version of this preprint was published at Plant and Soil on August 18th, 2021. See the published version at https://doi.org/10.1007/s11104-021-05088-4. 


\section{Abstract}

Aims

Arid ecosystem soil processes are strongly bottom-up controlled by resource scarcity. However, grazing intensification can induce changes through multiple pathways and spatio-temporal scales. For example, by changing litter quality and site environmental conditions. Our purpuse was to understand the relative importance of top-down and bottom-up controls of litter decomposition and $\mathrm{N}$ dynamics in the Patagonian grass-shrub steppes.

\section{Methods}

We performed three litterbag decomposition experiments to evaluate: i) the interactive effects of litter traits and site environmental conditions (grazed vs. exclosure communities) (reciprocal transplants in situ), ii) the net effect of litter traits in a common garden (ex situ), and iii) the net effect of site environmental conditions using a foreign common litter substrate (in situ). The study was performed on three pairs of sites with areas under a long-term exclosure (> 25 years) or under year-round sheep grazing. Local litter included main community species composition and was sorted by grass and shrubs material.

Results

Grazing exclusion did not significantly alter litter decomposition, either through changes in grass litter traits that control decomposition or through changes in the site environmental conditions. Nevertheless, $\mathrm{N}$ released during litter decomposition was $286 \%$ higher in exclosures than in grazing commumnities. The difference was associated to changes in the grass litter chemical quality. The effects were maintained when we integrated results from the entire litter community.

\section{Conclusion}

Our study suggests that decomposition rates in arid steppes are mainly bottom-up determined, but topdown controls shaping grass litter traits importantly alter the flux of $\mathrm{N}$ during decomposition.

\section{Introduction}

Herbivores' impacts on litter decomposition process and nutrient dynamics are key aspects of ecosystem functioning. However, and despite this subject has been actively studied in the last decade, generalizations are complex. Such complexity is partially due to the multiple pathways and spatiotemporal scales along which herbivores can affect different vegetation and soil components, and also through variations among ecosystems, livestock management practices and experimental approaches (Bardgett and Wardle 2003, Pastor et al. 2006, du Toit and Olff 2014, Wang and Wesche 2016, Zhou et al. 2016). Arid steppes are ecosystems where productivity is low, litter remains a long time as standing-dead material, the soil cover is irregular, and soil nutrient content is low (Kéfi et al. 2007). Wind and radiation generate changes in the availability and quality of the aboveground litter that enters the soil (Austin et al. 
2016, Throop and Belnap 2019). Such context from vegetation and environmental traits may entail a dominant bottom-up control on litter decomposition and other ecosystem processes. On the other hand, the main land-use in these ecosystems is grazing by domestic herbivores, which can exert a top-down control (Fig. 1). Grazing intensification is widely observed to change the composition of plant species and soil properties, both closely related to the litter decomposition process and nutrient fluxes (Bakker et al. 2009, Giese et al. 2009, 2013, Reichmann et al. 2013, Peco et al. 2017, Sun et al. 2018). Hence, the joint evaluation of bottom-up and top-down controls on the litter decomposition process and nutrient recycling should result in a better understanding of how grazing management can alter ecosystem functioning (Frank et al. 2017, Penner et al. 2019).

Top-down effects of herbivores may control ecosystem function through two main pathways (Hunter and Price 1991, Wardle et al. 2004). First, through intraspecific changes in vegetation traits, by altering growth rate and biomass allocation, and after a longer-term, by directionally shifting species composition (Fig. 1: vegetation pathway, Augustine and McNaughton 1998, Paruelo et al. 2008, Porensky et al. 2016, Niu et al. 2016, Sun et al. 2018). Large herbivores selectively graze species and plant parts with high tissue quality. In low productive ecosystems as arid steppes, grazers drive the dominance of aboveground litter with high C:N, high lignin or chemical defences content, which are traits generally slowing litter decomposition rates and nutrient flux (Bardgett and Wardle 2003, Semmartin et al. 2004, Díaz et al. 2007, Parton et al. 2007, Bakker et al. 2009). However, in arid steppes, the entire species pool entails a strong selection for traits adapted to low resource availability (Coley 1982, Milchunas and Lauenroth 1993, Adler et al. 2004, Fig. 1: bottom up controls on vegetation), which may mask the effect of grazing-induced changes in species composition on litter decomposition rates (Semmartin et al. 2004, Giese et al. 2009).

The second pathway of herbivore impacts is by changing the environmental conditions of decomposition (Fig. 1: environmental pathway, Bardgett and Wardle 2003, Schrama et al. 2013). Through biomass consumption and trampling, big herbivores may increase soil compaction and soil water evaporation, decreasing soil biotic activity and litter decomposition rates, and affecting $\mathrm{C}$ and $\mathrm{N}$ stocks (Giese et al. 2009, Golluscio et al. 2009, Eldridge et al. 2016, Wang et al. 2018). Hypothetically, top-down effects of herbivores may change the arid ecosystem function through both pathways, cascading down to the decomposition process and reducing $C$ and nutrients return to the soil (Fig. 1, Bardgett and Wardle 2003, Wang et al. 2015, 2018, Sun et al. 2018). Instead, if low quality and low activity of decomposers is a general pattern, despite the long-term influence or absence of herbivores, bottom-up controls defined by the ecosystem traits will regulate the decomposition process in these ecosystems (Semmartin et al. 2004, Giese et al. 2009, Penner et al. 2019, Fig. 1).

Community changes due to grazing impact mainly depend on herbivores guilds, the ecosystem herbivory history (coevolution) and soil and vegetation traits (Milchunas and Lauenroth 1993, Porensky et al. 2016 a, b, Wigley et al. 2020). Within a plant community, some of the species may show significant changes in their traits because of herbivory, while others may be more resistant to change (Vesk and Westbody 2001, Cingolani et al. 2005, Díaz et al. 2007). Most studies regarding grazing impacts on decomposition include either some individual species, the population of which increases or decreases with grazing (e.g. 
Semmartin et al. 2004), or local litter mixtures with pooled composition (e.g. Giese et al. 2009, Wang et al. 2015). Classifying the plant community into compartments, for example according to their sensitivity to disturbances such as grazing, can be very useful for the interpretation and extrapolation of results.

Arid steppe vegetation is commonly represented by two functional groups: tussock grasses and shrubs. Differently to other communities, where both woody and herbaceous vegetation change importantly with herbivore impact (e.g. Wigley et al. 2020), the Occidental District Patagonian steppe has shown a preserved grass-shrub proportion after the long-term exclusion from sheep grazing (Cipriotti and Aguiar 2005, 2010, Cipriotti et al. 2019). However, the long-term influence of sheep grazing intensification changed the identity of grass dominant species in the community, substantially decreasing palatable species (highly preferred by herbivores) and increasing non-preferred species (Cipriotti and Aguiar 2005, 2010, Oñatibia et al. 2015, 2020, Oñatibia and Aguiar 2019). Shrub species have shown few or idiosyncratic variations in their composition and abundance after long-term herbivore exclusions (Cipriotti and Aguiar 2005, 2010, Golluscio et al. 2009, Cesa and Paruelo 2011, Cipriotti et al. 2019). Thus, when grazing-induced changes in species composition occur mostly within one of the two dominant life forms, considering the community as a whole could mask the changes (Carrera et al. 2008), while considering only sensitive species could overestimate grazing effects (Semmartin et al. 2004). Notwithstanding the foregoing, the effects of grazing through the environmental pathway could have consequences on the litter decomposition of both vegetation components either affected or not by the vegetation pathway. Therefore, to analyze the top-down impacts of grazing on the litter decomposition process, it is necessary to combine the effects trough the vegetation pathway and the environment pathway, and to consider the relative abundance of main vegetation components (Fig. 1).

Our objective was to analyse the effects of long-term grazing exclusion compared to year-round sheep grazing on the decomposition process. Top-down effects were assessed by analysing two type of ecosystem pathways, which influence the decomposition of community components represented by grasses and shrub species (Fig. 1). Based on local published data (see above), we assumed that shrub species composition and abundance did not differ between areas under long-term grazing or its exclusion. Specifically, we performed three litterbag decomposition experiments to analyse: (i) the single effect of the environmental pathway (site conditions) affecting shrubs, and the interactive effects of the vegetation (litter traits) and environmental pathways affecting grasses (reciprocal transplants in situ), (ii) the net effect of the vegetation pathway, by changing the quality of aboveground grass litter (common ex situ garden), and (iii) the net effect of the environmental pathway by changing litter decomposition of a foreign common substrate in grazing and exclosure areas. Finally, we calculated the decomposition and $\mathrm{N}$ release flux, by integrating results from grasses and shrubs and considering its proportional biomass contribution in the ecosystem (scaling-up). Our three complementary experiments approach allowed the joint assessment of bottom-up and top-down litter decomposition controls.

\section{Methods}

\section{Study system}


The study was conducted in the experimental field station of INTA (Instituto Nacional de Tecnología Agropecuaria) located in Río Mayo, Chubut Province, Argentina ( $45^{\circ} 41^{\prime} \mathrm{S}, 70^{\circ} 16^{\prime} \mathrm{W}$ ). Mean annual precipitation is $132 \mathrm{~mm}, 60 \%$ of which falls between April and September; mean annual temperature is $9.3^{\circ} \mathrm{C}$ (average data between 1982-2019, INTA 2020). Soils are coarse-textured Aridisols, with gravels and low organic matter (0.4\%), and low net $\mathrm{N}$ mineralization $\left(0.28 \mathrm{mg} \mathrm{m}^{-2}\right.$, Yahdjian et al. 2006). Vegetation corresponds to the Occidental district of Patagonian arid steppes (Cipriotti et al. 2012, see dominant species in Table 1). Total vegetation cover varies between 30 to $65 \%$, and aboveground net primary productivity ranges between 27 to $86 \mathrm{~g} \mathrm{~m}^{-2}$ year $^{-1}$ (depending on precipitation) divided between tussock grasses and shrubs in equal contribution (Cipriotti et al. 2012). Sheep were introduced in the region towards the end of the 19th century and became an important economic activity. Stocking rates in the study field have been $\sim 0.2$ sheep ha- ${ }^{-1}$ during the last 50 years, which represents an intermediate grazing intensity for the region (Oñatibia and Aguiar 2016). After $>25$ years of sheep grazing exclosure, vegetation structure and physiognomy remained without important modifications, but tussock grasses dominance changed by increasing the relative biomass of palatable grasses (Cipriotti and Aguiar 2005).

Table 1

Species composition and each species abundance of vegetation components (grasses and shrubs) representing exclosure and grazing communities. Numbers represent the relative aboveground litter mass (proportion within each) in grazing and exclosure plots $(n=3)$, based on previous studies of the western Patagonian arid steppe.

\begin{tabular}{|lll|}
\hline & Exclosure & Grazing \\
\hline Grasses & & \\
\hline Pappostipa speciosa Trin. et Rupr & 0.25 & 0.70 \\
\hline Pappostipa humilis Cav. & 0.20 & 0.20 \\
\hline Poa ligularis Nees ap. Steud & 0.50 & 0.10 \\
\hline Bromus pictus Hook & 0.05 & 0.00 \\
\hline Shrubs & & \\
\hline Mulinum spinosum Cav. Pers & 0.40 & 0.40 \\
\hline Adesmia volckmanii Philippi & 0.30 & 0.30 \\
\hline Senecio filaginoides De Candolle & 0.30 & 0.30 \\
\hline
\end{tabular}

\section{Experimental Design}

Three litterbag decomposition experiments were performed to test our model (Fig. 1). We selected three paddocks under a long-term sheep year-round grazing (350-700 has), each one including an adjacent long-term grazing exclosure (blocks, $n=3$ ). Exclosures impeded big herbivores (mainly sheep) but allowed small wild herbivore access, and were established 28 (8 ha), 39 (5 ha) and 57 years ( 1 ha) before 
the start of the experiment. Inside each paired plot (grazing and exclosure), four areas were randomly selected, at a minimum distance of $50 \mathrm{~m}$ from each other, where all experimental determinations were performed (24 experimental areas). The experimental sampling and determinations were performed in the field in the period between 2010 and 2013. In this period, mean annual temperature ranged between 8.8 and $10.1^{\circ} \mathrm{C}$, whereas annual precipitations between 140 and $152.1 \mathrm{~mm}$ year $^{-1}$ (INTA 2020).

\section{Litter and soil determinations}

We sorted the steppe vegetation community into two groups: grasses and shrubs. Grass composition was different between grazing and exclosure conditions (Table 1, based on Golluscio et al. 2009, Oñatibia et al. 2015). Grasses comprised the four dominant species of the community. Other Poaceae species and forbs were excluded due to their low relative abundance. Shrubs comprised the three dominant species, and composition was the same between grazing and exclosure conditions (Cipriotti and Aguiar 2005, Golluscio et al. 2009, Oñatibia and Aguiar 2016). Litter was collected from individual plants dispersed within a broad area of the experimental sites during summer 2010. We selected fresh (yellow tissue) aboveground litter parts contributing important biomass amounts, avoiding coarse woody tissues with very low decomposability or very small leaves (in shrubs). Grass litter included blades, sheaths and culms, and shrubs litter included fine branches and thorns. Origin of grass species from grazing or exclosure plots was preserved, shrub litter from grazing and exclosures was pooled under a 50:50 mixture to build litterbags. Litter was placed in $15 \times 20 \mathrm{~cm}$ fiberglass bags with $2 \mathrm{~mm}$ mesh (Robertson et al. 1999), containing $3 \mathrm{~g}$ air-dry weight with different litter species proportions (Table 1). The litter mesh size allowed access to soil microorganisms and mesofauna (Robertson et al. 1999, Araujo et al. 2012).

Litter quality at the beginning of the experiments was evaluated through five fresh litter random samples from each litter type (shrubs, grasses from grazing and exclosure conditions, and Lolium arundinaceum, see below). In these samples we estimated initial handling losses (weight pre-post experiment establishment), water content $\left(60^{\circ} \mathrm{C}\right.$ oven-dried for 48 hours), ash content (ground samples 4 hour burning in $500{ }^{\circ} \mathrm{C}$ muffle) and total $\mathrm{C}$ and $\mathrm{N}$ concentration (LECO-CR12 dry combustion analyser and semi-micro Kjeldahl method, respectively) (Robertson et al. 1999).

Site environment under exclosure and grazing conditions was characterized by soil samples collected in the same sampling areas as the experiments ( $4 \times 6$ plots). Variables measured were soil water gravimetric content (wet-dry weight, $100{ }^{\circ} \mathrm{C}$ oven), soil bulk density $\left(\mathrm{g} \mathrm{cm}^{-3}\right)$, and soil total $\mathrm{C}$ and $\mathrm{N}$ concentration (LECO-CR12 dry combustion analyser and semi-micro Kjeldahl method, respectively). In each sampling area, 2-3 sub-samples were collected using a $4 \mathrm{~cm}$ diameter and $10 \mathrm{~cm}$ height cylinder (4 groups per site and grazing condition). Nutrient (C-N) stock (ton/ha) was estimated from concentration and bulk density data. Soil temperature was measured with a digital thermometer buried 2-4 cm from soil surface (3 sub-samples). Litterbags collected from the field were carefully cleaned, oven-dried during 48 hours at $60-70^{\circ} \mathrm{C}$, and then weighed with a high precision scale. Total $\mathrm{N}$ content (semi-micro Kjeldahl method) was estimated in all samples from the latest harvest date (25 months for experiments 1 and 3 , and 12 months for experiment 2, see below). 
Experiment 1: Top-down (vs. bottom-up) effects through vegetation and environmental pathways.

The environmental pathway was represented by the soil properties under long-term grazing or exclosure sites (paired plots), and the vegetation pathway was represented by the species traits related to grazing or exclosure. This second pathway was only considered for the grass vegetation component (Table 1). Hence, under our experimental approach, the decomposition of shrubs was affected by the environmental pathway and the decomposition of grasses was affected by both the environmental and vegetation pathways (Fig. 1). To evaluate the interaction between pathways, litter from the grass component was tested under a reciprocal transplant experiment, where litter collected from grazing and exclosure plots (vegetation, Table 1) was decomposed in both paired grazing and exclosure plots (environments). Experiment 1 started in January 2011, bags were placed in four experimental areas per plot, each containing 3 litter types with 3 samples, which were collected after 6, 12, and 25 months. Litterbags were located randomly within the grass matrix (avoiding sites below shrubs), fixed to the soil surface, and protected from animal trampling with wire nets. We predicted that grazing exclosure accelerates litter decomposition through both the vegetation pathway and the environmental pathway. This experiment also allows comparing the effects of bottom-up controls (litter and environmental local traits) with the effects of top-down controls (grazing changes in litter and environmental traits) affecting litter decomposition.

Experiment 2: Net top-down effects through the vegetation pathway (litter traits).

The purpose was to isolate the effects of litter traits from those bottom-up controls due to the environmental conditions of the arid steppe. To do this, we conducted an experiment in an ex-situ common garden in a temperate location (litterbags exposed to site climate and soil conditions). Litterbags included grasses, with the composition from grazing and exclosure conditions, and shrubs (Table 1). Experiment 2 started in December 2011 and was established in an experimental field in the Faculty of Agronomy University of Buenos Aires ( $34^{\circ} 35^{\prime} \mathrm{S}, 58^{\circ} 35^{\prime} \mathrm{W}$ ), under a randomised complete block design ( $n=5$ blocks) with 3 collection dates $(2,6$, and 12 months). We predicted that grazing exclosure accelerates decomposition and $\mathrm{N}$ release rates by increasing the chemical quality of grasses. The combination with results from Experiment 1 allows evaluating differences between litter types under local (arid) vs. foreign (mesic) environmental conditions.

Experiment 3: Net top-down effects through the environmental pathway (site condition).

In this case, we aimed to evaluate the environmental pathway, regardless of the bottom-up effects that determined the litter traits in arid conditions. Hence, we used the litter from a temperate-origin grass (fescue, Lolium arundinaceum (Schreb) Darbysh) as a common substrate, which was decomposed in grazed and exclosure plots (in situ). This grass species is a foreign litter for local decomposers, collected from temperate grasslands $\left(35^{\circ} 55^{\prime} \mathrm{S}, 61^{\circ} 10^{\prime} \mathrm{W}\right.$ ), and not present in the Occidental District. $L$. arundinaceum was also included in experiment 2 , as a reference. This experiment was carried out simultaneously with experiment 1 . We predicted that grazing exclosure accelerates decomposition rates 
and $\mathrm{N}$ release by increasing soil organic matter and soil water retention (Giese et al. 2009, Schrama et al. 2013, Eldridge et al. 2016).

\section{Estimating top-down effects on ecosystem fluxes}

We estimated mass and $\mathrm{N}$ fluxes during litter decomposition by scaling results through the biomass production (Table 1). The green biomass in peak production in these ecosystems with a very short growing season can be used as a proxy for the annual net primary productivity (Sala and Austin 2000). Biomass cover per species was estimated in early summer season (2012) through a point intercept method, in two random $50 \mathrm{~m}$ transects per plot with 101 points per transect (paired plots in 3 grazingexclosure blocks). Covers from each of the three dominant grass species and the three dominant shrub species were converted to green and total biomass, using the model proposed by Flombaum and Sala $(2007,2008)$. Results from each vegetation component cover (\%) and their biomass values matched those reported in preliminary studies (summarized in Cipriotti et al. 2012). Green biomass production was assumed to be equivalent to litter's annual biomass input. Nitrogen biomass was calculated from $\mathrm{N}$ concentration of grasses and shrubs measuared in litter mixtures as detailed above (see Table 2). Under an additive model assumption (non interactive effects), decomposition rates $\left(\mathrm{g} \mathrm{g} \mathrm{g}^{-1} \mathrm{y}^{-1}\right)$ of grasses and shrubs (or $\mathrm{N}$ released from litter) from each plot were weighted by their biomass $\left(\mathrm{g} \mathrm{m}^{-2}\right)$, and then summed. We predicted that the (additive) mixture of grass and shrub litter would still show differences in the decomposition process between grazing and exclosure conditions, displaying a top-down control.

Table 2

Grazing vegetation pathway: Common garden decomposition and litter chemical traits of litter mixtures of grasses from exclosure-origin (E-grasses), from grazing-origin (G-grasses) and shrubs species. Values show mean \pm S.E. $(n=5$, ANOVA $d f=2,8)$. Letters indicate differences across treatments $(P<0.05$, Tukey tests).

\begin{tabular}{|llllll|}
\hline & E-grasses & G-grasses & Shrubs & $\boldsymbol{F}$ & $\boldsymbol{P}$ \\
\hline $\begin{array}{l}\text { Litter decay rate (k, year } \\
\text { 1) }\end{array}$ & $\begin{array}{l}1.16 \pm 0.167 \\
\mathrm{a}\end{array}$ & $1.04 \pm 0.16 \mathrm{a}$ & $0.83 \pm 0.02 \mathrm{a}$ & 2.97 & 0.1085 \\
\hline Litter N released (\%) & $\begin{array}{l}23.65 \pm 7.22 \\
\mathrm{a}\end{array}$ & $\begin{array}{l}-85.46 \pm 19.05 \\
\mathrm{~b}\end{array}$ & $12.36 \pm 5.14 \mathrm{a}$ & 17.19 & 0.0013 \\
\hline Litter Total C (\%) & $\begin{array}{l}43.86 \pm 0.42 \\
\mathrm{~b}\end{array}$ & $42.42 \pm 0.05 \mathrm{c}$ & $47.93 \pm 0.13 \mathrm{a}$ & 125.1 & $<0.0001$ \\
\hline Litter Total N (\%) & $0.32 \pm 0.01 \mathrm{~b}$ & $0.17 \pm 0.02 \mathrm{c}$ & $0.48 \pm 0.02 \mathrm{a}$ & 67.41 & $<0.0001$ \\
\hline Litter C:N (ratio) & $\begin{array}{l}136.8 \pm 6.83 \\
\mathrm{~b}\end{array}$ & $249.8 \pm 19.81 \mathrm{a}$ & $100.79 \pm 5.0 \mathrm{~b}$ & 39.04 & $<0.0001$ \\
\hline
\end{tabular}

\section{Data analyses}

Decay rates were calculated for each sample through the slope $(k)$ of the negative exponential function of dry weight of litter remaining organic mass $\left(\mathrm{m}_{1} / \mathrm{m}_{0}\right)$ through time $\left[\mathrm{t}\right.$, years, $\left[\mathrm{m}_{1} / \mathrm{m}_{0}=\mathrm{e}^{(-k \mathrm{t})}\right]$. Nitrogen released from the decomposing litter was estimated from the quantity of $\mathrm{N}$ at the end of the experiment 
relative to the initial $\mathrm{N}$ quantity $\left\{\mathrm{Nrel}=100-\left[\left(\mathrm{N}_{1} * \mathrm{~m}_{1}\right) /\left(\mathrm{N}_{0} * \mathrm{~m}_{0}\right)\right]\right\}$, being $\mathrm{N}$ and $\mathrm{m}, \mathrm{N}$ concentration and dry mass at final $\left.{ }_{1}\right)$ and initial $\left({ }_{0}\right)$ time of decomposition experiment. Data were analysed with linear mixedeffect models using R software (version 2.13.0, package nlme, function Ime) (Pinheiro et al. 2011, R Core Team 2011). In a random intercept model, grazing condition was used as a fixed effect, and a nested structure for data in experimental areas, plots and blocks represented the random effects. A constant variance function structure (varldent) was included when variance heterogeneity was detected (Pinheiro et al. 2011). For variables with more than one determination date (soil water content and soil temperature), data were both analysed for each date and in a complete model including the date in the nested structure.

\section{Results}

\section{Top-down effects through vegetation and environmental pathways: Experiment 1}

The decomposition rates from grasses litter, both originated under grazing or exclosures, were similar between grazing and exclosure environments (Vegetation $x$ Environment. $F_{1,42}=3.14, P=0.08$, Fig. $2 \mathrm{~A}$ ). Shrub litter decomposed $5 \%$ faster in exclosure than in grazing areas $\left(F_{1,20}=10.27, P<0.004\right.$, Fig. $\left.2 \mathrm{~B}\right)$. Grass litter decay rates were on average 1.5 -fold faster than shrub litter $\left(F_{1,42}=85.57, P<0.0001\right)$.

$\mathrm{N}$ released during decomposition was strongly dependent on the origin of grasses (Fig. 2C). Grasses from exclosures released, on average $286 \%$ more $N$ than grasses from grazing conditions, and this difference was observed under both grazing and exclosure environments (Vegetation: $F_{1,42}=44.8, P<0.0001$, Vegetation $x$ Environment. $\left.F_{1,42}=0.19, P=0.66\right)$. Shrub litter released, on average, $14 \%$ more $N$ in exclosures than in grazing sites, but the difference was marginally significant $\left(F_{1,20}=3.99, P=0.06\right.$, Fig. 2D). Grasses originated in exclosures released 1.06-fold more $N$ than shrubs (Fig. 2D), whereas grasses from grazing conditions released 0.25 -fold more $\mathrm{N}$ than shrubs $\left(F_{1,40}=53.41, P<0.0001\right)$. Nitrogen was, on average, released from all litter substrates. Only a few samples (7 of 24) from grazingorigin grasses showed $\mathrm{N}$ retention (between 1.5 and $36 \% \mathrm{~N}$ ). The variation of $\mathrm{N}$ release among samples (in situ) was higher in grasses from grazing-origin ( $\mathrm{CV}=189 \%$ ), compared to grasses from exclosureorigin (CV $=22 \%$ ), and shrubs (CV $=18 \%$ ).

\section{Top-down effects through the vegetation pathway: Experiment 2}

Grass litter from exclosure-origin had $45 \%$ higher C:N ratio compared to grazing-origin grasses (Table 2). Despite differences in tissue quality, litter decay rates in a common garden (ex-situ) did not depend on the origing of grasses (Table 2). However, after one year of decomposition, the exclosure-origin grasses released $128 \%$ more $\mathrm{N}$ than those of grazing-origin, which qualitatively retained $\mathrm{N}$ during decomposition (Table 2). Shrub litter had the highest C (\%) and $\mathrm{N}(\%)$ contents, but its $\mathrm{C}: \mathrm{N}$ ratio was similar to the 
exclosure-origin grasses (Table 2). Unlike in situ observations, shrub litter had similar decomposition rates than grass litter in the common garden (Table 2).

\section{Top-down effects through the environmental pathway: Experiment 3}

Environmental conditions of exclosure plots were slightly different from those of grazing plots (Table 3). Soil total C (\%) and N (\%) concentrations were $13 \%$ and $17 \%$ higher $(p<0.05)$ in exclosure than in grazing environments, respectively. Soil C:N ratio and total $\mathrm{C}$ or $\mathrm{N}$ stocks (ton ha ${ }^{-1}$ ) were equivalent between grazing conditions (Table 3 ). Soil bulk density in exclosures was $7 \%$ lower than in grazing environments $(p<0.05$, Table 3$)$. Concerning soil gravimetric moisture and temperature, only one out of four estimation dates were different between grazing conditions, being $5 \%$ and $11 \%$ higher in exclosures than in grazing plots, respectively $(P<0.05$ in January 2011 , Table 3$)$. 
Table 3

Grazing environmental pathway: soil properties in exclosures and grazing conditions. Values represent mean \pm S.E. at $0-10 \mathrm{~cm}$ soil depth, and ANOVA parameters for grazing fixed effect. Soil moisture and temperature variables include model parameters of date and grazing fixed effects.

\begin{tabular}{|c|c|c|c|c|c|}
\hline & Exclosure & Grazing & $D f$ & $F$ & $P$ \\
\hline Soil Total C (\%) & $0.53 \pm 0.04$ & $0.47 \pm 0.01$ & 1,35 & 4.67 & 0.038 \\
\hline Soil Total N (\%) & $0.07 \pm 0.01$ & $0.06 \pm 0.00$ & 1,35 & 5.05 & 0.031 \\
\hline Soil C:N (ratio) & $7.85 \pm 0.11$ & $7.74 \pm 0.31$ & 1,35 & 0.06 & 0.80 \\
\hline Soil Bulk Density $\left(\mathrm{g} \mathrm{cm}^{-3}\right)$ & $1.36 \pm 0.06$ & $1.45 \pm 0.12$ & 1,59 & 5.55 & 0.022 \\
\hline Soil Total C stock (tn ha-1) & $6.93 \pm 0.22$ & $7.19 \pm 0.55$ & 1,20 & 0.32 & 0.58 \\
\hline Soil Total $\mathrm{N}$ stock (tn ha ${ }^{-1}$ ) & $0.92 \pm 0.05$ & $0.92 \pm 0.08$ & 1,20 & $<0.01$ & 0.99 \\
\hline \multicolumn{6}{|l|}{$\begin{array}{l}\text { Soil gravimetric moisture } \\
(\%, 0-10 \mathrm{~cm} \text { depth })\end{array}$} \\
\hline January 2011 & $3.78 \pm 0.57$ & $3.67 \pm 0.92$ & 1,33 & 6.38 & 0.017 \\
\hline June 2011 & $4.41 \pm 0.58$ & $4.16 \pm 0.32$ & 1,35 & 2.88 & 0.099 \\
\hline January 2012 & $1.67 \pm 0.24$ & $1.39 \pm 0.27$ & 1,35 & 0.60 & 0.44 \\
\hline February 2013 & $6.82 \pm 0.17$ & $6.86 \pm 0.22$ & 1,59 & 0.02 & 0.89 \\
\hline Grazing & & & 1,162 & 37.66 & $<0.0001$ \\
\hline Date & & & 3,33 & 357.01 & $<0.0001$ \\
\hline Grazing $\times$ Date & & & 3,162 & 4.10 & 0.008 \\
\hline \multirow{2}{*}{\multicolumn{6}{|c|}{$\begin{array}{l}\text { Soil temperature } \\
\left({ }^{\circ} \mathrm{C}, \sim 2 \mathrm{~cm} \text { depth }\right)\end{array}$}} \\
\hline & & & & & \\
\hline January 2011 & $34.51 \pm 2.90$ & $30.70 \pm 2.53$ & 1,59 & 40.21 & $<0.0001$ \\
\hline June 2011 & $3.87 \pm 1.47$ & $3.45 \pm 2.94$ & 1,59 & 1.72 & 0.19 \\
\hline January 2012 & $32.61 \pm 3.68$ & $30.68 \pm 2.01$ & 1,59 & 3.35 & 0.07 \\
\hline February 2013 & $25.31 \pm 2.31$ & $24.19 \pm 1.96$ & 1,59 & 1.07 & 0.31 \\
\hline Grazing & & & 1,20 & 2.65 & 0.12 \\
\hline Date & & & 3,66 & 311.8 & $<0.0001$ \\
\hline Grazing $\times$ Date & & & 3,66 & 1.11 & 0.35 \\
\hline
\end{tabular}


The environmental pathway did not affect the decomposition process of the foreign grass substrate ( $L$. arundinaceum, Decomposition rate, $\mathrm{k}$ : Exclosured plots $=0.43 \pm 0.03$; Grazing plots $=0.37 \pm 0.01$; $\left.F_{1,20}=3.04, P=0.096\right)$. Litter $\mathrm{N}$ release was not different between exclosured and grazing plots either ( $55 \% \mathrm{~N}, F_{1,20}=3.19, P=0.09$ ). The values of $L$. arundinaceum litter decay rate observed under the arid steppe local environmental conditions (in situ) were, on average, $24 \%$ and $52 \%$ faster than local litter from grasses and shrubs, respectively and independently from grazing conditions (Litter type: $F_{3,84}=$ 58.17, $P<0.0001$, Environment. $F_{1,4}=1.61, P=0.27$; Litter x Env.: $\left.F_{3,84}=2.18, P=0.10\right)$. However, $\mathrm{N}$ release was similar to that from shrubs and grasses from exclosures, and $273 \%$ higher than that from grazing origin grasses (Litter type: $F_{3,84}=21.09, P<0.0001$, Environment. $F_{1,4}=0.97, P=0.38$; Litter $\mathrm{x}$ Env.: $\left.F_{3,84}=1.04, P=0.37\right)$.

Under the common garden environment (ex situ), L. arundinaceum decay rate differed from the decay rate values of local litter, being on average 2.6-fold faster than all steppe litter components (Decomposition rate, $\mathrm{k}: 2.62 \pm 0.24, F_{3,12}=20.53, P=0.0001$ ). $\mathrm{N}$ release was $193 \%$ and $461 \%$ higher than shrubs and grasses from exclosures $\left(\mathrm{N}\right.$ release $\left.=0.69 \pm 0.03, F_{3,9}=76.15, P=0.0001\right)$. L. arundinaceum litter had a lower $\mathrm{C}$ concentration (average \pm S. E.: $40.24 \% \pm 0.04 \%)$ and a higher $\mathrm{N}$ concentration $(0.56 \%$ $\pm 0.02 \%)$ compared to local litters $\left(F_{3}=60-213, p<0.0001\right)$.

\section{Top-down effects on litter decomposition fluxes}

Top-down effects were consistent after scaling-up the mass and $\mathrm{N}$ fluxes during decomposition. The average green biomass was $573 \mathrm{~kg} \mathrm{ha}^{-1}$ (38\% grasses and $62 \%$ shrubs biomasses). These results were not altered by grazing conditions (Table 4). Litter decomposition flux was $13 \%$ lower in exclosured than in grazing conditions $\left(F_{1,20}=6.81, P=0.02\right.$, Fig. $\left.3 \mathrm{~A}\right)$. The grass component had $25 \%$ lower decomposition flux under exclosured than grazing conditions $\left(F_{1,20}=9.78, P=0.005\right)$. There were no differences in shrub litter decomposition flux $\left(F_{1,20}=1.70, P=0.21\right)$. Total flux of $\mathrm{N}$ released from litter was $40 \%$ higher in exclosured than grazing conditions $\left(F_{1,20}=19.35, P=0.0003\right.$, Fig. 3B). The effect on $\mathrm{N}$ flux from the grass component was $451 \%$ higher in exclosures $\left(F_{1,20}=50.68, P<0.0001\right)$, while the shrub component $\mathrm{N}$ flux did not differ between grazing conditions $\left(F_{1,20}=1.79, P=0.20\right)$. Results pattern was similar when the total biomass data were used instead of green biomass in the apportionment (Online Resource 1). 
Table 4

Green aboveground biomass and N content. Data was estimated from vegetation cover data and Flombaum and Sala (2007) models for green biomass in peak production. $\mathrm{N}$ concentration was based on litter data from Table 2. Values show mean \pm S.E. $(n=3)$.

\begin{tabular}{|lrll|}
\hline \multicolumn{1}{|c|}{ Exclosure } & Grazing & Anova: Grazing \\
\hline \multicolumn{1}{|l}{ Green biomass $\left(\mathrm{kg} \mathrm{ha}^{-1}\right)$} & & \\
\hline Grasses & $208.2 \pm 8.6$ & $253.9 \pm 29.8$ & $\mathrm{~F}_{1,8}=2.83, \mathrm{P}=0.14$ \\
\hline Shrubs & $364.9 \pm 43.8$ & $382 \pm 17.9$ & $\mathrm{~F}_{1,8}=0.06, \mathrm{P}=0.81$ \\
\hline Shrubs + Grasses & $573.1 \pm 40$ & $635.9 \pm 25.6$ & $\mathrm{~F}_{1,8}=1.38, \mathrm{P}=0.27$ \\
\hline N in green biomass $\left(\mathrm{kg} \mathrm{ha}^{-1}\right)$ & & \\
\hline Grasses & $0.67 \pm 0.02$ & $0.47 \pm 0.04$ & $\mathrm{~F}_{1,8}=9.64, \mathrm{P}=0.015$ \\
\hline Shrubs & $1.75 \pm 0.19$ & $1.82 \pm 0.07$ & $\mathrm{~F}_{1,8}=0.065, \mathrm{P}=0.81$ \\
\hline Shrubs + Grasses & $2.42 \pm 0.19$ & $2.28 \pm 0.06$ & $\mathrm{~F}_{1,8}=0.21, \mathrm{P}=0.66$ \\
\hline
\end{tabular}

\section{Discussion}

The long-term grazing or its exclusion had different consequences for decomposition rates and the release of $\mathrm{N}$ during decomposition in Patagonian steppes. Both the grass component litter traits (vegetation pathway) and the soil environment (environmental pathway) differed according to grazing history (long-term exclosures or grazing conditions). However, broadly, decomposition rates did not differ between grazing conditions, which indicates that this critical ecosystem process is strongly bottom-up controlled. Nonetheless, the top-down effect was evident on the release of $\mathrm{N}$ during litter decomposition since exclosures markedly increased the $\mathrm{N}$ release, especially through the vegetation pathway. These effects were also observed when considering the flux of $\mathrm{N}$ during decomposition, by integrating the biomass production and decomposition rates from the two main components of the community: grasses and shrubs. Our experimental approach, based on three complementary experiments evaluating the conceptual model from Fig. 1, allowed a joint evaluation of the bottom-up and top-down controls in the litter decomposition process and nutrient recycling. It allowed connecting community components and ecosystems pathways to analyse the complex impacts of grazing management on ecosystem functioning. It also guided the scaling-up modelling (Fig. 3).

\section{Bottom-up controls on litter decomposition rates}

We observed no evident top-down effects from the long-term grazing history in grass decomposition rates from either vegetation or environmental pathways. These results were consistent among the experiments. 
Given the differences found in both litter and environmental traits, our expectations were of a greater decomposer carbon use efficiency and higher decomposition rates under exclosure than under grazing conditions. Litter chemical quality was higher in grasses from exclosures (lower C:N), possibly because of the higher abundance of palatable species (Table 2, Semmartin et al. 2004). Also, soil compaction was lower and the surface-layer stock of $\mathrm{C}$ and $\mathrm{N}$ was higher in exclosures than in grazing plots (Table 3 , Golluscio et al. 2009). The effect of grazin through the environmental pathway was slightly evident in the case of shrubs, in which the decomposition rate was faster in exclosure than in grazing plots (Fig. 2). But apparently, this effect was not determinant to alter the decomposition process when litter had a lower $C$ content, as in the case of grasses (see Table 2 and $L$. arundinaceum results). The high and long influence of abiotic photodegradation in arid lands might erase grazing effects on the biotic controls of litter decomposition (Pastor et al. 2007, Golluscio et al. 2009, Wang et al. 2015). However, radiation can also stimulate litter biotic decomposition by selective degradation of lignin (Austin et al. 2016). This, in combination with an enhancement of soil environmental conditions, may explain the faster decomposition rates of shrub litter (with higher lignin than grasses) in exclosure plots. The lack of differences in the grass component decomposition rates between grazing and exclosures suggests the manifestation of a strong bottom-up control in the decomposition process.

Bottom-up controls regulate the rates of decomposition by shaping both the abiotic environment, as soil cover, water and nutrient availability, and the overall traits in the plant community (Frank et al. 2017, Penner et al. 2019). Studies in semiarid grasslands reached similar results, also suggesting a strong bottom-up control of decomposition process. In Inner Mongolian semi-arid grasslands, grazing generates important impacts on vegetation traits and environmental conditions. But neither decomposition rates nor $\mathrm{N}$ recycling were sensitive to grazing exclosures, moderate winter grazing or long-term heavily grazed conditions (Giese et al. 2009). In Yellowstone grasslands, the effect of migratory grazing ungulates (elk) did not alter litter decomposition rates (Penner and Frank 2019). In these two studies, decomposition rates were found to be highly dependent on precipitations variations, hence a bottom-up control. Under our experimental approach, some other results reinforce this hypothesis. All litter types decomposing under the arid environmental conditions released $\mathrm{N}$ during decomposition, whereas at the common garden under a temperate and mesic environment, grazing-origin grasses retained $\mathrm{N}$ and exclosure-origin grasses and shrubs released it. Furthermore, the quality differences between $L$. arundinaceum and the arid-originated litter were highly evident in the common garden, but less noticeable in the arid steppe environmental conditions. Hence, these results suggest that the decomposition process under in situ arid environmental conditions appeared to express a low sensitivity to litter quality differences. As mentioned before, the exception was observed in shrub litter, which manifested higher differences to grasses in situ than in the common garden. Possibly, top-down controls would emerge as important under a stronger disturbance scenario, where differences in shrub species abundance and composition become evident, and divergence in grass composition stronger (Oñatibia and Aguiar 2019, Cipriotti et al. 2019).

\section{Top-down controls on $\mathbf{N}$ released during litter decomposition}


Unlike the high stability observed in decomposition rates from grasses, we detected a high sensitivity of $\mathrm{N}$ released from grass litter to long-term sheep grazing or exclosure, especially mediated by the vegetation pathway (Table 2, Fig. 2). $\mathrm{N}$ released from litter was considerably higher in long-term exclosures than in grazing conditions. These results remark the relevance of grazing impact on local $\mathrm{N}$ cycle during litter decomposition, resembling observations in other arid and semiarid systems, although the directions and magnitudes of the effects are variable (e.g. Shariff et al. 1994, Carrera et al. 2008, Bakker et al. 2009, Giese et al. 2013, Bosco et al. 2016, Sun et al. 2018). Nitrogen release or retention during litter decomposition is highly controlled by litter $\mathrm{N}$ concentration and the stoichiometric requirements of the decomposers (Manzoni et al. 2008, Bakker et al. 2009). It is posible that grasses originated under grazing conditions have a C:N ratio near the critical value for net immobilization during decomposition (Manzoni et al. 2008). We submit that this critical value was reached in the common garden (mesic) environment (net $\mathrm{N}$ retention), but under the arid steppe environment, the threshold was not reached and in most cases we estimated a $\mathrm{N}$ release. This, again, may be the result of a complex interaction between the photodegradation and the activity of decomposers, the balance of which might differ between arid and mesic environments. Also, local arid decomposers might exert a higher adaptation to access $\mathrm{N}$ from lowquality litter and from soil transfering than mesic decomposers (Zechmeister-Bolstenstern et al. 2015, Bonanomi et al. 2017).

The differences in the release of $\mathrm{N}$ during litter decomposition due to herbivory history (grazing or exclosure) remained when the decomposition process was additively integrated by considering the relative contribution of grasses and shrubs in the community (Fig. 1, Fig. 3). Litter decomposition flux was higher under grazing conditions after integrating results from shrubs and grasses and their local annual biomass production. This highlights that the effects of grazing on these processes must consider variations in vegetation and environmental pathways, the dynamics of vegetation components and their biomass productivity, in order to analyse impacts under a proper scenario. Despite the higher contribution of shrubs in the flux of $\mathrm{N}$, it was not enough to mask differences in the flux of $\mathrm{N}$ in the grass component (Fig. 3). The lower $\mathrm{N}$ release from grasses originated under grazing conditions may be related to the higher proportion of the low palatable species Pappostipa speciosa in the litter mixture (Table 1). This species has the lowest leaf $\mathrm{N}$ content compared to other local grasses (Semmartin et al. 2004, Yahdjian et al. 2006). It has been observed to be dominant under moderate grazing intensity, but its abundance is weakened both under exclosure or higher grazing intensity conditions (Oñatibia et al. 2015). Hence, this result might be highly dependent on local species composition and grazing intensity.

\section{Conclusions}

Excluding sheep grazing for $a>25$ years term produced changes in vegetation and site environmental traits. Such changes resulted in acceleration of the $\mathrm{N}$ cycling but did not promote important changes in the rate of litter decomposition, either for grasses or shrubs components. In other words, our study suggests that arid traits are controlling the Patagonian steppe decomposition rates from bottom-up drivers, and this control is large enough to erase the effects of grazing history. However, top-down controls that shape part of litter community traits are important enough to alter the flux of $\mathrm{N}$ during 
decomposition. Our study showed that the multiple-experiment approach allowed disentangling a complex network of effects and responses. We achieved this by including different community litter components and species traits and environmental changes promoted by contrasting grazing histories. These complementary studies enhanced our capacity to predict grazing disturbance consequences on ecosystem functioning.

\section{References}

Adler PB, Milchunas DG, Lauenroth WK, et al (2004) Functional traits of graminoids in semi-arid steppes: A test of grazing histories. J Appl Ecol 41:653-663. https://doi.org/10.1111/j.0021-8901.2004.00934.x

Araujo PI, Yahdjian L, Austin AT (2012) Do soil organisms affect aboveground litter decomposition in the semiarid Patagonian steppe, Argentina? Oecologia 168:221-230. https://doi.org/10.1007/s00442-0112063-4

Augustine DJ, McNaughton SJ (1998) Ungulate effects on the functional species composition of plant communities: herbivore selectivity and plant tolerance. J Wildl Manage 62:1165-1183.

https://doi.org/10.2307/3801981

Austin AT, Méndez MS, Ballaré CL (2016) Photodegradation alleviates the lignin bottleneck for carbon turnover in terrestrial ecosystems. Proc Natl Acad Sci 113:201516157.

https://doi.org/10.1073/pnas.1516157113

Bakker ES, Knops JMH, Milchunas DG, et al (2009) Cross-site comparison of herbivore impact on nitrogen availability in grasslands: The role of plant nitrogen concentration. Oikos 118:1613-1622. https://doi.org/10.1111/j.1600-0706.2009.17199.x

Bardgett RD, Wardle DA (2003) Herbivore-mediated linkages between aboveground and belowground communities. Ecology 84:2258-2268. https://doi.org/10.1890/02-0274

Bisigato AJ, Bertiller MB (1997) Grazing effects on patchy dryland vegetation in northern Patagonia. J Arid Environ 36:639-653. https://doi.org/10.1006/jare.1996.0247

Bonanomi G, Cesarano G, Gaglione SA, et al (2017) Soil fertility promotes decomposition rate of nutrient poor, but not nutrient rich litter through nitrogen transfer. Plant Soil 412:397-411.

https://doi.org/10.1007/s11104-016-3072-1

Bosco T, Bertiller MB, Carrera AL (2016) Combined effects of litter features, UV radiation, and soil water on litter decomposition in denuded areas of the arid Patagonian Monte. Plant Soil 406:71-82. https://doi.org/10.1007/s11104-016-2864-7

Carrera AL, Bertiller MB, Larreguy C (2008) Leaf litterfall, fine-root production, and decomposition in shrublands with different canopy structure induced by grazing in the Patagonian Monte, Argentina. Plant 
Soil 311:39-50. https://doi.org/10.1007/s11104-008-9655-8

Cesa A, Paruelo JM (2011) Changes in vegetation structure induced by domestic grazing in Patagonia (Southern Argentina). J Arid Environ 75:1129-1135. https://doi.org/10.1016/j.jaridenv.2011.04.003

Cingolani AM, Posse G, Collantes MB (2005) Plant functional traits, herbivore selectivity and response to sheep grazing in Patagonian steppe grasslands. J Appl Ecol 42:50-59. https://doi.org/10.1111/j.13652664.2004.00978.x

Cipriotti PA, Aguiar MR (2005) Effects of grazing on patch structure in a semi-arid two-phase vegetation mosaic. J Veg Sci 16:57-66. https://doi.org/10.1111/j.1654-1103.2005.tb02338.x

Cipriotti PA, Aguiar MR (2010) Resource partitioning and interactions enable coexistence in a grass-shrub steppe. J Arid Environ 74:1111-1120. https://doi.org/10.1016/j.jaridenv.2010.05.006

Cipriotti PA, Aguiar MR (2012) Direct and indirect effects of grazing constrain shrub encroachment in semi-arid Patagonian steppes. Appl Veg Sci 15:35-47. https://doi.org/10.1111/j.1654-

109X.2011.01138.x

Cipriotti PA, Aguiar MR, Wiegand T, Paruelo JM (2019) Combined effects of grazing management and climate on semi-arid steppes: Hysteresis dynamics prevent recovery of degraded rangelands. J Appl Ecol 56:2155-2165. https://doi.org/10.1111/1365-2664.13471

Coley PD, Bryant JP, Chapin FS (1985) Resource Availability and Plant Antiherbivore Defense. Science (80- ) 230:895-899. https://doi.org/10.1017/СВ09781107415324.004

Díaz S, Lavorel S, Mclntyre S, et al (2007) Plant trait responses to grazing - A global synthesis. Glob Chang Biol 13:313-341. https://doi.org/10.1111/j.1365-2486.2006.01288.x

du Toit JT, Olff H (2014) Generalities in grazing and browsing ecology: Using across-guild comparisons to control contingencies. Oecologia 174:1075-1083. https://doi.org/10.1007/s00442-013-2864-8

Eldridge DJ, Poore AGB, Ruiz-Colmenero M, et al (2016) Ecosystem structure, function, and composition in rangelands are negatively affected by livestock grazing. Ecol Appl 26:1273-1283.

https://doi.org/10.1890/15-1234

Flombaum P, Sala OE (2007) A non-destructive and rapid method to estimate biomass and aboveground net primary production in arid environments. J Arid Environ 69:352-358.

https://doi.org/10.1016/j.jaridenv.2006.09.008

Flombaum P, Sala OE (2008) Higher effect of plant species diversity on productivity in natural than artificial ecosystems 
Frank DA, Wallen RL, Hamilton EW, et al (2018) Manipulating the system: How large herbivores control bottom-up regulation of grasslands. J Ecol 106:434-443. https://doi.org/10.1111/1365-2745.12884

Giese M, Brueck H, Gao YZ, et al (2013) N balance and cycling of Inner Mongolia typical steppe: A comprehensive case study of grazing effects. Ecol Monogr 83:195-219. https://doi.org/10.1890/120114.1

Giese M, Gao YZ, Zhao Y, et al (2009) Effects of grazing and rainfall variability on root and shoot decomposition in a semi-arid grassland. Appl Soil Ecol 41:8-18.

https://doi.org/10.1016/j.apsoil.2008.08.002

Golluscio RA, Austin AT, García Martínez GC, et al (2009) Sheep grazing decreases organic carbon and nitrogen pools in the patagonian steppe: Combination of direct and indirect effects. Ecosystems 12:686697. https://doi.org/10.1007/s10021-009-9252-6

Hunter MD, Price PW (1992) Playing Chutes and Ladders: Heterogeneity and the Relative Roles of Bottom-Up and Top- Down Forces in Natural Communities. Ecology 73:724-732. https://doi.org/10.2307/1940152

INTA (2020) Estación Agrometeorológica EEA INTA Río Mayo. In: Sist. Inf. Patagon. Sur. Inst. Nac. Tecnol. Agropecu. http://sipas.inta.gob.ar/?q=agrometeorologia-detalle-estacion\&idEstacion=19.

Kéfi S, Rietkerk M, Alados CL, et al (2007) Spatial vegetation patterns and imminent desertification in Mediterranean arid ecosystems. Nature 449:213-217. https://doi.org/10.1038/nature06111

Manzoni S, Jackson RB, Trofymow JA, Porporato A (2008) The global stoichiometry of litter nitrogen mineralization. Science (80- ) 321:684-686. https://doi.org/10.1126/science.1159792

Milchunas DG, Lauenroth WK (1993) Quantitative effects of grazing on vegetation and soils over a global range of environments. Ecol Monogr 63:327-366. https://doi.org/10.2307/2937150

Niu K, He J-S, Lechowicz MJ (2016) Grazing-induced shifts in community functional composition and soil nutrient availability in Tibetan alpine meadows. J Appl Ecol 53:1554-1564.

https://doi.org/10.1111/1365-2664.12727

Oñatibia GR, Aguiar MR, Semmartin M (2015) Are there any trade-offs between forage provision and the ecosystem service of $\mathrm{C}$ and $\mathrm{N}$ storage in arid rangelands? Ecol Eng 77:26-32.

https://doi.org/10.1016/j.ecoleng.2015.01.009

Oñatibia GR, Aguiar MR (2016) Continuous moderate grazing management promotes biomass production in Patagonian arid rangelands. J Arid Environ 125:73-79.

https://doi.org/10.1016/j.jaridenv.2015.10.005 
Oñatibia GR, Aguiar MR (2019) Grasses and grazers in arid rangelands: Impact of sheep management on forage and non-forage grass populations. J Environ Manage 235:42-50.

https://doi.org/10.1016/j.jenvman.2019.01.037

Oñatibia GR, Amengual G, Boyero L, Aguiar MR (2020) Aridity exacerbates grazing-induced rangeland degradation: A population approach for dominant grasses. J Appl Ecol 57:1999-2009.

https://doi.org/10.1111/1365-2664.13704

Parton W, Silver WL, Burke IC, et al (2007) Global-Scale Similarities in Nitrogen Release Patterns During Long-Term Decomposition. Science (80- ) 315:361-364. https://doi.org/10.1126/science.1134853

Paruelo JM, Pütz S, Weber G, et al (2008) Long-term dynamics of a semiarid grass steppe under stochastic climate and different grazing regimes: A simulation analysis. J Arid Environ 72:2211-2231. https://doi.org/10.1016/j.jaridenv.2008.07.010

Pastor J, Cohen Y, Hobbs NT (2006) The roles of large herbivores in ecosystem nutrient cycles, in: In: Danell K, Bergström R, Duncan P, Pastor J (eds) Large herbivore ecology, ecosystem dynamics and conservation. Cambridge University Press., New York, pp 289-325

Peco B, Navarro E, Carmona CP, et al (2017) Effects of grazing abandonment on soil multifunctionality: The role of plant functional traits. Agric Ecosyst Environ 249:215-225.

https://doi.org/10.1016/j.agee.2017.08.013

Penner JF, Frank DA (2019) Litter Decomposition in Yellowstone Grasslands: The Roles of Large Herbivores, Litter Quality, and Climate. Ecosystems 22:929-937. https://doi.org/10.1007/s10021-0180310-9

Pinheiro JC, Bates D (2000) Mixed-effects models in S and S-PLUS. Springer, New York

Pinheiro JC, Bates DM, DebRoy S, et al (2018) nlme: Linear and Nonlinear Mixed Effects Models. R package version 3.1-137.

Porensky LM, Mueller KE, Augustine DJ, Derner JD (2016) Thresholds and gradients in a semi-arid grassland: long-term grazing treatments induce slow, continuous and reversible vegetation change. J Appl Ecol 53:1013-1022. https://doi.org/10.1111/1365-2664.12630

Porensky LM, Derner JD, Augustine DJ, Milchunas DG (2017) Plant Community Composition after $75 \mathrm{Yr}$ of Sustained Grazing Intensity Treatments in Shortgrass Steppe. Rangel Ecol Manag 70:456-464. https://doi.org/10.1016/j.rama.2016.12.001

R Core Team (2018) R: A language and environment for statistical computing.

Reichmann LG, Sala OE, Peters DPC (2013) Water controls on nitrogen transformations and stocks in an arid ecosystem. Ecosphere 4:1-17. https://doi.org/10.1890/ES12-00263.1 
Robertson GP, Coleman DC, Bledsoe CS, Sollins P (1999) Standard soil methods for long-term ecological research. Oxford University Press, New York

Schrama M, Veen GFC, Bakker ESL, et al (2013) An integrated perspective to explain nitrogen mineralization in grazed ecosystems. Perspect Plant Ecol Evol Syst 15:32-44. https://doi.org/10.1016/j.ppees.2012.12.001

Semmartin M, Aguiar MR, Distel RA, et al (2004) Litter quality and nutrient cycling affected by grazinginduced species replacements along a precipitation gradient. Oikos 107:148-160. https://doi.org/10.1111/j.0030-1299.2004.13153.x

Shariff AR, Biondini ME, Grygiel CE (1994) Grazing intensity effects on litter decomposition and soil nitrogen mineralization. J Range Manag 47:444-449. https://doi.org/10.2307/4002994

Sun Y, He XZ, Hou F, et al (2018) Grazing increases litter decomposition rate but decreases nitrogen release rate in an alpine meadow. Biogeosciences 15:4233-4243. https://doi.org/10.5194/bg-15-42332018

Throop HL, Belnap J (2019) Connectivity dynamics in dryland litter cycles: Moving decomposition beyond spatial stasis. Bioscience 69:602-614. https://doi.org/10.1093/biosci/biz061

Vesk PA, Westoby M (2001) Predicting plant species' responses to grazing. J Appl Ecol 38:897-909. https://doi.org/10.1046/j.1365-2664.2001.00646.x

Wang Y, Gong JR, Liu M, et al (2015) Effects of land use and precipitation on above- and below-ground litter decomposition in a semi-arid temperate steppe in Inner Mongolia, China. Appl Soil Ecol 96:183-191. https://doi.org/10.1016/j.apsoil.2015.07.010

Wang Y, Wesche K (2016) Vegetation and soil responses to livestock grazing in Central Asian grasslands: a review of Chinese literature. Biodivers Conserv 25:2401-2420. https://doi.org/10.1007/s10531-0151034-1

Wang Z, Yuan X, Wang D, et al (2018) Large herbivores influence plant litter decomposition by altering soil properties and plant quality in a meadow steppe. Sci Rep 8:9089. https://doi.org/10.1038/s41598018-26835-1

Wardle DA, Bardgett RD, Klironomos JN, et al (2004) Ecological Linkages Between Aboveground and Belowground Biota. Science (80- ) 304:1629-1633. https://doi.org/10.1126/science.1094875

Wigley BJ, Augustine DJ, Coetsee C, et al (2020) Grasses continue to trump trees at soil carbon sequestration following herbivore exclusion in a semiarid African savanna. Ecology 101:. https://doi.org/10.1002/ecy.3008 
Yahdjian L, Sala OE, Austin AT (2006) Differential controls of water input on litter decomposition and nitrogen dynamics in the patagonian steppe. Ecosystems 9:128-141. https://doi.org/10.1007/s10021004-0118-7

Zechmeister-Boltenstern S, Keiblinger KM, Mooshammer M, et al (2015) The application of ecological stoichiometry to plant-microbial-soil organic matter transformations. Ecol. Monogr. 85:133-155

Zhou G, Zhou X, He Y, et al (2017) Grazing intensity significantly affects belowground carbon and nitrogen cycling in grassland ecosystems: a meta-analysis. Glob Chang Biol 23:1167-1179. https://doi.org/10.1111/gcb.13431

\section{Figures}




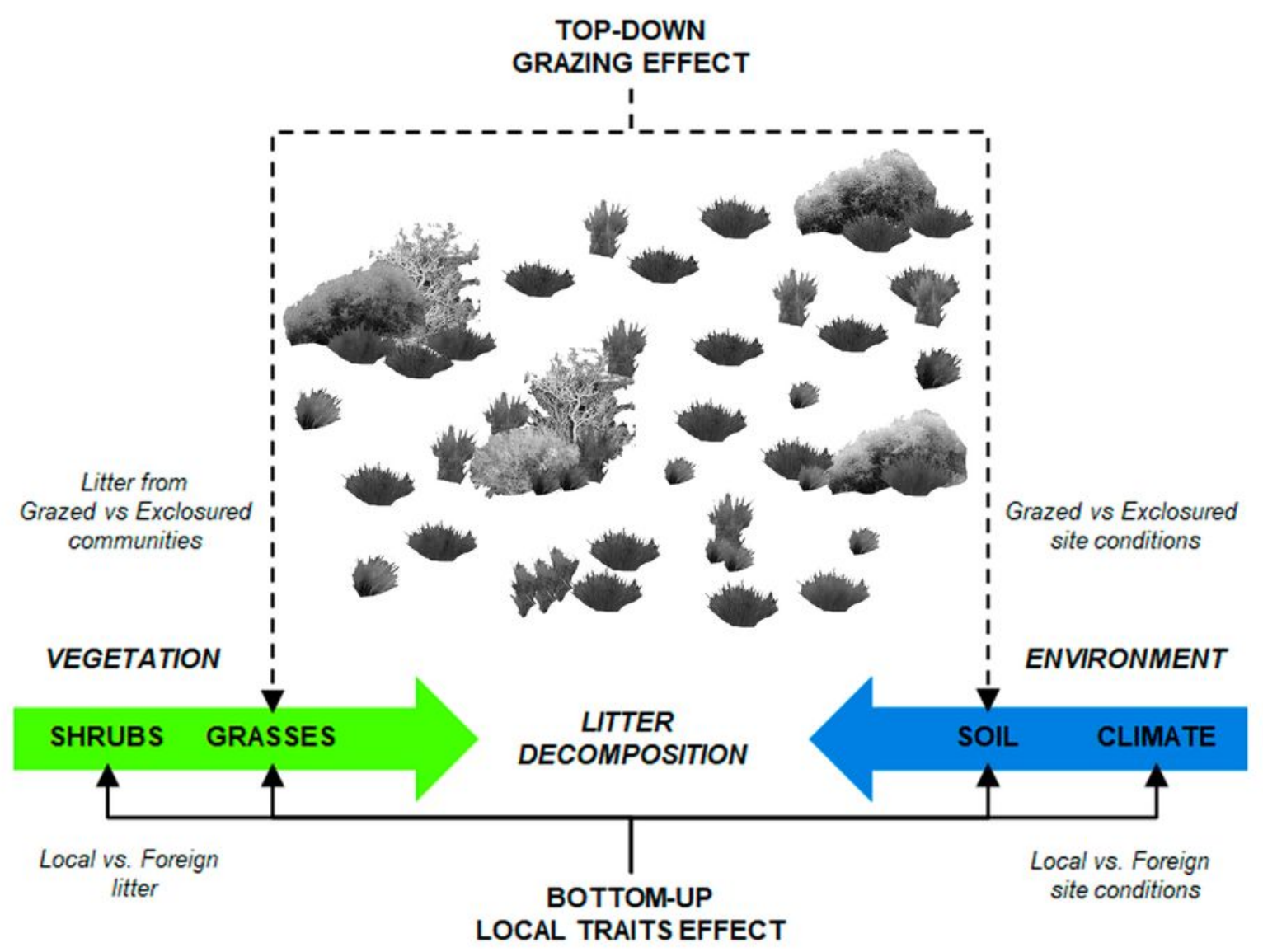

\section{Figure 1}

Conceptual model on the top-down and bottom-up controls of the decomposition process. Ecosystem pathways are represented by vegetation traits (left) and the environmental conditions from soil and climate (right). Bottom-up effects (solid black arrows) are represented by local conditions shaping vegetation and environmental traits. Top-down grazing effects (dashed black arrows) are represented by the effects on grasses traits (vegetation pathway), and on the soil conditions (environmental pathway). 
Shrub component is assumed not altered by the vegetation pathway in the Occidental District of the Patagonian steppe (no arrow). Arrows connectors denote the experimental approaches that allow evaluating each effect.
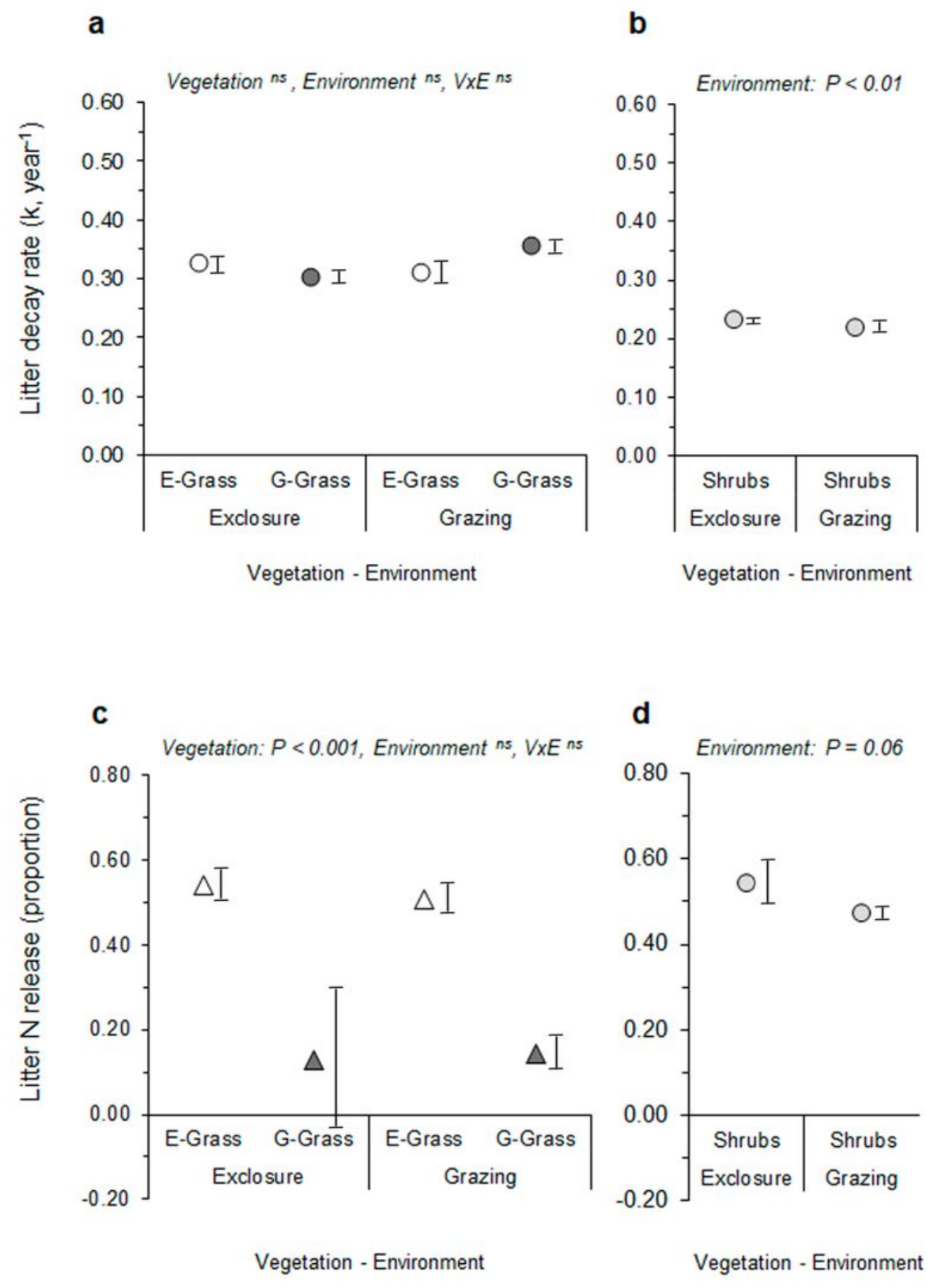

\section{Figure 2}

Reciprocal transplant litter decay rate ( $k$. year- 1 , panels a and b) and $\mathrm{N}$ release (proportion, panels $\mathrm{c}$ and d) affected by grazing management. The symbols show mean values and the segments the standard 
errors of grasses from exclosure-origin (grey triangles) and grazing-origin (white triangles, panels a and c) and shrubs (panels $b$ and d), decomposing in exclosure and grazing environments. Figure captions summarise the fixed effects from the vegetation pathway and the environmental pathways.

a

Grasses: $P<0.01$, Shrubs ${ }^{n s}$, Total: $P<0.05$

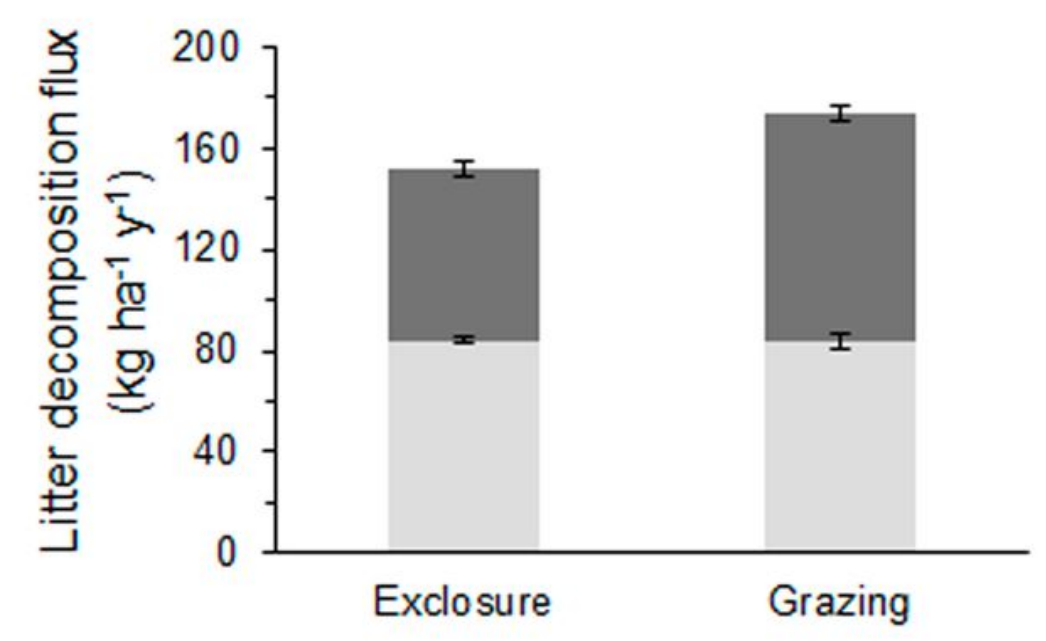

Shrubs $\approx$ Grasses

b

Grasses: $P<0.0001$, Shrubs ${ }^{n s}$, Total: $P<0.0001$

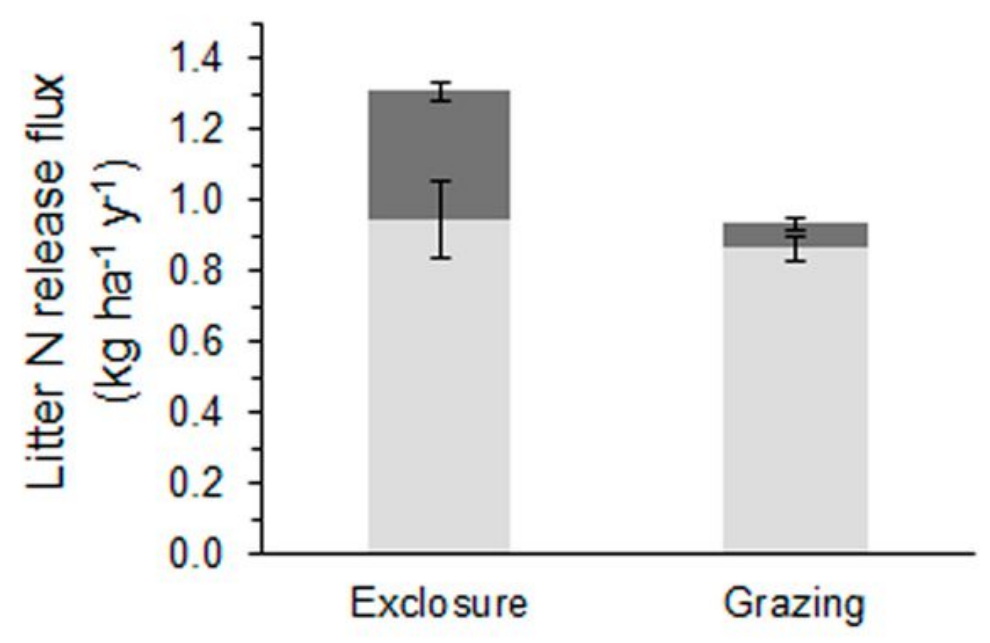

Figure 3

Litter decomposition flux (a) and $\mathrm{N}$ flux during litter decomposition (b) from grass and shrubs components (kg MS ha-1 year-1). The total flux corresponds to their additive integration. Grasses-origin is 
preserved from each grazing condition. Data show mean and standard error values, calculated per experimental unit in grazing and exclosure plots, using local litter decomposition or $\mathrm{N}$ release rates values and their aboveground green biomass.

\section{Supplementary Files}

This is a list of supplementary files associated with this preprint. Click to download.

- OnlineResource1.eps

- PhotoExperiment.jpg 